\title{
The Effect of Temperature on the Synthesis and Assembly of Proticine 3 Particles by Proteus mirabilis
}

\author{
By BERNARD W. SENIOR \\ Department of Medical Microbiology. The Unicersity of Dundee Medical School, \\ Ninewells Hospital. Dundee DDI 9SY, UK
}

(Received 2 April 1984; revised 4 June 1984)

\begin{abstract}
Proteus mirabilis $\mathrm{CW} 977$ produced high yields of the bacteriocin proticine 3 upon mitomycin C induction of cultures growing at $30^{\circ} \mathrm{C}$. The proticine was purified and found to have a relative density of 1.299 and to be composed of 10 proteins assembled into structures resembling contractile phage tails. When induction was performed at $41^{\circ} \mathrm{C}$ neither proticine particles nor proticine activity was detected, although the growth rate of cells and degree of lysis were indistinguishable from that at $30^{\circ} \mathrm{C}$. Failure in proticine production was due to a $41^{\circ} \mathrm{C}$ sensitive stage occurring between 60 and $90 \mathrm{~min}$ after the addition of mitomycin $\mathrm{C}$. During this period at $30^{\circ} \mathrm{C}$, two proteins of mol. wt 58000 and 41000 were formed. These proteins were associated with events leading to the formation of proticine particles with biological activity. When the production of both proteins was prevented either by chloramphenicol or as a result of mutation or through sampling before they were formed, no proticine particles were found nor proticine activity detected. The synthesis of both proteins was also inhibited at $41^{\circ} \mathrm{C}$. Co-electrophoresis of the labelled proteins with unlabelled purified proticine confirmed that the protein of mol. wt $\mathbf{5 8 0 0 0}$ was a proticine structural protein. The protein of mol. wt 41000 was not a structural component of proticine and its role, if any, in proticine 3 production is possibly that of an assembly protein.
\end{abstract}

\section{INTRODUCTION}

Most strains of Proteus mirabilis have the potential to produce bacteriocins called proticines. In surveys of different strains by different workers, the proportion found to be proticinogenic has increased from $55 \%$ in the first study (Cradock-Watson, 1965) to $74 \%$ (Adler et al., 1971), and more recently from $84 \%$ (Senior, 1977) to $89 \%$ (Senior \& Sweeney, 1984) through the discovery of more discriminating sensitive indicator strains. Some 13 different proticines, each with a specific inhibitory action on one of 13 different indicator strains, have been defined and used in the development of stable, highly discriminating epidemiological typing schemes for $\boldsymbol{P}$. mirabilis and $\boldsymbol{P}$. culgaris (Senior, 1977: Senior \& Larsson, 1983).

In a survey of strains of Proteus associated with urinary tract infections, based on these proticine typing schemes, most strains of $P$. mirabilis associated with severe upper renal tract infection produced the proticine designated proticine 3 . These strains were seldom found in either the urine from symptomless patients with post-operative urinary tract infections or the faeces of healthy individuals (Senior, 1979). Others have also reported the high virulence of proticine 3 producing strains (Williams et al. 1983). Whether the proticine itself is a virulence factor or whether its determinant genes are associated with genes of other, as yet unidentified. virulence factors is not known. However, proticine 3 has been purified recently and has a complex structure of 11 proteins assembled into a contractile phage-tail-like form composed of an internal core surrounded by a contractile sheath with a base plate and fibres (Senior, 1983).

During the synthesis of proticine 3, a protein of mol. wt 58000 is formed late in the induction cycle. It has been suggested that this protein might be involved in the assembly of the proticine 3 
structural components (Senior, 1983). This paper reports on investigations into the role of this protein and the effect of temperature on the synthesis and assembly of component proteins into biologically active proticine 3 structures.

\section{METHODS}

Bacterial strains. Proteus mirabilis CW977 was the standard proticine 3 producing strain which was sensitive to both cephaloridine and chloramphenicol (each at $25 \mu \mathrm{g} \mathrm{ml} \mathrm{I}^{-1}$ ); $P$. vulgaris $\mathrm{CW} 712$ was the standard indicator strain sensitive to proticine 3 and resistant to $100 \mu \mathrm{g}$ cephaloridine $\mathrm{ml}^{-1}: P$. mirabilis D3-11 and D3-34 were mutants of $\boldsymbol{P}$. mirabilis $\mathrm{CW} 977$ defective in proticine 3 production. All strains were maintained as pure cultures on nutrient agar slopes in sealed bottles at $4^{\circ} \mathrm{C}$.

Culture media. Nutrient broth (CM67-Oxoid) and MacConkey agar (CM7-Oxoid) were prepared as directed by the manufacturers. GSYE medium was the minimal salts medium of Grabow \& Smit (1967) supplemented with $50 \mathrm{mg}$ yeast extract $\mathrm{I}^{-1}$ (L21-Oxoid) (Senior, 1983). Agarose medium was MacConkey broth (CM5a-Oxoid) solidified with $0.5 \%(w / v)$ agarose.

Induction of proticine production and isotope labelling of cells. Proticine 3 production was induced by adding mitomycin $\mathrm{C}$ to a final concentration of $1 \mu \mathrm{g} \mathrm{ml}^{-1}$ to exponentially growing cultures $\left(O D_{s s_{0}} 0 \cdot 25\right)$ of $P$. mirabilis CW977 in GSYE, incubated either statically in a water bath or with aeration in a shaker incubator at $30{ }^{\circ} \mathrm{C}$ in the dark. At intervals, $50 \mu$ ] samples of culture were labelled with $20 \mu \mathrm{Ci} \mathrm{L-}-4,5-{ }^{3} \mathrm{H}$ )leucine $\mathrm{ml}^{-1}$ (specific activity $13 \mathrm{l}$ $\mathrm{Ci}^{\mathrm{mmol}}{ }^{-1}: 4.85 \mathrm{TBq} \mathrm{mmol}^{-1}$ - Amersham). Incorporation of isotope was stopped either by the addition of chloramphenicol to a final concentration of $250 \mu \mathrm{g} \mathrm{m}]^{-1}$ and the later addition of $\left.50 \mu\right]$ disruption buffer [0.05 $\mathrm{M}$ Tris/ $/ \mathrm{Cl}_{\text {, }} \mathrm{pH} 6 \cdot 7$, containing $5 \%(\mathrm{w} / \mathrm{v}) \mathrm{SDS}, 20 \%$ (w/v) glycerol, $6 \mathrm{M}$-urea, $1 \%(\mathrm{v} / \mathrm{v}) 2$-mercaptoethanol and a trace of bromophenol blue as tracking dye] or by the direct addition of $50 \mu \mathrm{l}$ disruption buffer. The labelled preparations were boiled for $2 \mathrm{~min}$ and stored at $-20^{\circ} \mathrm{C}$.

Measurement of growth and sonication of cells. Growth was plotted throughout the proticine induction period by measuring on a Pye-Unicam SP6-550 spectrophotometer the OD $_{s 50}$ of the culture against a blank of sterile medium with an uninduced culture as a control. At intervals, samples of culture were taken and the cells disrupted by sonication for $1 \mathrm{~min}$ at ice-water temperature. After the addition of a few drops of chloroform and a brief shake, the sonicate was centrifuged for $I \mathrm{~min}$ at $12000 \mathrm{~g}$ on a microcentrifuge to remove chloroform and cell debris. The clear sterile supernatant was tested for proticine activity and, after staining, examined by electron microscopy.

Electron microscopy. Preparations were applied to copper grids coated with Formvar and carbon. They were stained with either $2 \%(\mathrm{w} / \mathrm{v})$ phosphotungstic acid $(\mathrm{pH} 7)$ or methylamine tungstate and examined in a Jeol 100 CX electron microscope.

Detection and assay of proticine actitity. A young culture of the proticine 3 indicator strain (CW 712) was streaked across a MacConkey agar plate and covered with a loopful $(50 \mu \mathrm{l})$ of the neat or diluted (in $5 \mathrm{mM}-\mathrm{Tris} / \mathrm{HCl}$ buffer, $\mathrm{pH} 7 \cdot 2$, hereinafter referred to as Tris-buffer) chloroform-sterilized proticine preparation. After incubation, either for a few hours or overnight at $37^{\circ} \mathrm{C}$, the plate was examined for inhibition of growth of the indicator organism. The reciprocal of that dilution giving complete inhibition of growth was taken to be the titre of proticine activity.

Purification of proticine 3. Mitomycin C-induced GSYE cultures of $P$. mirabilis $C W 977$ were incubated until the cells lysed. Cell debris was removed from the lysate by centrifugation at $10000 \mathrm{~g}$ for $5 \mathrm{~min}$ at $4^{\circ} \mathrm{C}$ and proticine activity concentrated from the supernatant by centrifugation at $100000 \mathrm{~g}$ for $2 \mathrm{~h}$ at $4^{\circ} \mathrm{C}$. Sedimented crude proticine was resuspended in a minimal volume of $20 \%(w / w)$ sucrose in Tris-buffer and volumes of $0.25 \mathrm{ml}$ were each layered on $3.75 \mathrm{ml}$ stepped sucrose gradients $\left(0.25 \mathrm{ml} 25 \%\right.$ sucrose on $0.5 \mathrm{ml} 30 \%$ sucrose on $3 \mathrm{ml} 40^{\circ}{ }_{0}$ sucrose in Tris-buffer). The gradients were centrifuged (brake off) at $5000 \mathrm{~g}$ for $30 \mathrm{~min}$ at $4{ }^{\circ} \mathrm{C}$. By collecting the $20^{\circ}{ }_{\mathrm{o}}^{\circ}$ and $25 \%$ sucrose layers, most of the proticine could be retrieved free from contaminating fimbriae and cellular fragments. The layers were pooled, dialysed free from sucrose against Tris-buffer at $4^{\circ} \mathrm{C}$ and proticine was further purified and concentrated by caesium chloride buoyant density gradient centrifugation. Gradient fractions high in proticine activity were subsequently collected, dialysed against Tris-buffer and either stored at $4^{\circ} \mathrm{C}$ or concentrated by ethanol precipitation and stored at $-20^{\circ} \mathrm{C}$

Caesium chloride buvyant density centrifugation of proticine 3 and analysis of fractions. Volumes of $3 \mathrm{ml}$ of proticine preparations in Tris-buffer were added to centrifuge tubes holding $1.2 \mathrm{~g} \mathrm{CsCl}$ and the contents mixed. The tubes were filled with liquid paraffin (density $0.88 \mathrm{~g} \mathrm{ml}^{-1}$ ) and centrifuged in an angled rotor at $100000 \mathrm{~g}$ for $20 \mathrm{~h}$ at $6{ }^{\circ} \mathrm{C}$. The $\mathrm{CsCl}$ gradient was fractionated into 6-drop $(-115 \mu \mathrm{l})$ fractions. The refractive index of fractions was measured on an Abbe refractometer. The amount of labelled protein in fractions was measured by pipetting $20 \mu \mathrm{l}$ samples on to Whatman GF/F glass microfibre filters which were subsequently immersed for at least $30 \mathrm{~min}$ in ice-cold $10 \%(w / v)$ trichloroacetic acid to precipitate protein, washed twice in $5 \%(w / v)$ ice-cold trichloroacetic acid, dried with ethanol and ether and finally immersed in scintillation fluid and counted. The $A_{280}$ of fractions diluted in Tris-buffer was determined on a Pye Unicam SP6-550 spectrophotometer against a buffer control. Biologically active proticine was detected by the assay of fractions as described above. 
Isolation of mutants defective in proticine 3 production. Exponentially growing nutrient broth cultures of $P$. mirabilis CW977 were mutagenized in $0.05 \mathrm{M}$-phosphate buffer ( $\mathrm{pH} \mathrm{6.0)}$ for $45 \mathrm{~min}$ with $100 \mu \mathrm{g} \mathrm{m}]^{-1} \mathrm{~N} \cdot \mathrm{methyl}^{-}$ $N^{\prime}$-nitro- $N$-nitrosoguanidine according to the method of Adelberg et al. (1965). Cells were subsequently washed in phosphate buffer, resuspended to volume in fresh nutrient broth and incubated for $5 \mathrm{~h}$ at $37^{\circ} \mathrm{C}$. A volume of $0 \cdot 1 \mathrm{ml}$ of an appropriate dilution of the culture was mixed with $5 \mathrm{ml}$ molten, cooled agarose medium and evenly poured over the agar surface of a MacConkey agar plate. When the medium had set, the surface of the seeded agarose was sterilized in order to prevent surface growth by inverting the plate and resting it for 1 min on the rim of a glass Petri dish holding chloroform. After allowing toxic vapours to evaporate, the plate was incubated at $30^{\circ} \mathrm{C}$ for $24 \mathrm{~h}$. The surface was resterilized with chloroform as before for $1 \mathrm{~min}$. A volume of $0.1 \mathrm{ml}$ of a diluted culture of $P$. tulgaris CW712 was mixed with $2.5 \mathrm{ml}$ molten, cooled agarose medium and poured evenly over the plate. When the medium had set the surface was sterilized with chloroform as before for $30 \mathrm{~s}$ and the plate incubated overnight at $30^{\circ} \mathrm{C}$. Those colonies of $\boldsymbol{P}$. mirabilis $\mathrm{CW} 977$ which failed to inhibit the growth of $\boldsymbol{P}$. vulgaris $\mathrm{CW} 712$ were picked. cultured in nutrient broth and plated for single colonies on MacConkey agar plates. Those colonies which gave cultures which were neither inhibitory to $P$. vulgaris $C W 712$ nor sensitive to proticine 3 but were sensitive to $25 \mu \mathrm{g} \mathrm{ml} \mathrm{m}^{-1}$ cephaloridine were deduced to be mutants of $P$. mirabilis $C W 977$ defective in proticine production. They were stored on nutrient agar slopes in sealed bottles at $4^{\circ} \mathrm{C}$.

Polyacrylamide gel electrophoresis and fluorography. The components of proticine 3 were analysed by SDS discontinuous polyacrylamide gel electrophoresis after the method of Laemmli (1970). Standard proteins of mol. wts from 20100 to 66000 or ${ }^{14} \mathrm{C}$-labelled proteins (Amersham) of mol. wts from 14700 to 200000 were used as markers. Samples were electrophoresed into slabs of a $4 \%(w / v)$ acrylamide stacking gel over a $10 \%(w / v)$ acrylamide resolving gel at $20 \mathrm{~mA}$ per gel at $4{ }^{\circ} \mathrm{C}$ until the tracking dye reached the bottom of the gel. Gels were then either fixed overnight in $10 \%(v / v)$ glacial acetic acid in water or stained overnight in $0.1{ }^{\circ}$. $(w / v)$ Coomassie brilliant blue $R 250$ in $25 \%(\mathrm{v} / \mathrm{v})$ 2-propanol and $10^{\circ}(\mathrm{v} / \mathrm{v})$ glacial acetic acid in water and subsequently destained by gentle washing in several changes of $10 \%(\mathrm{v} / \mathrm{v}) 2$-propanol and $10 \%(\mathrm{v} / \mathrm{v})$ glacial acetic acid in water. For fluorography, fixed gels were dehydrated in DMSO and soaked in a solution of $22 \%(w / v) 2.4-$ diphenyloxazole in DMSO, as described by Bonner \& Laskey (1974) and Laskey \& Mills (1975). The gels were washed in water, dried under vacuum, exposed to an X-ray film at $-70^{\circ} \mathrm{C}$ for an appropriate period and the film developed.

\section{RESULTS}

\section{Structure and composition of proticine 3}

When fractions from $\mathrm{CsCl}$ gradients in which partially pure proticine 3 had been centrifuged to equilibrium were analysed, proticine activity was found to be concentrated into a single narrow band of protein which consisted of numerous phage-tail-like structures (see Fig. 1) when examined under the electron microscope. Some were uncontracted and in the shape of a nail, whereas others were in the form of a rocket in which the outer sheath had contracted to reveal a hollow internal core protruding through a base plate to which fibres were attached. In some cases the internal core was lying free from the empty contracted sheath. No complete phages or phage-head-like structures were seen. Analysis of purified proticine by SDS discontinuous polyacrylamide gel electrophoresis revealed 10 proteins of mol. wts $82000,76000,58000,51000$, $48000,46000,36000,30000,28000$ and 23500 , the 48000 protein being the major constituent (Fig. 2).

\section{Kinetics of proticine 3 production}

The addition of mitomycin C to GSYE cultures of $P$. mirabilis $C W 977$ growing exponentially at $30^{\circ} \mathrm{C}$ induced production of high titres of proticine 3 within $3 \mathrm{~h}$. A typical response is shown in Fig. 3. Mitomycin was without effect on growth rate until about $90 \mathrm{~min}$ after its addition when growth rate appeared to decline and subsequently cells began to lyse. Biologically active proticine 3 was first detected and proticine particles first seen in the supernatants of sonicated induced cultures sampled $90 \mathrm{~min}$ after the addition of mitomycin C. No structural components of proticine were seen by electron microscopy in the supernatants of sonicates taken before biological activity was detected. No proticine activity was detected and no proticine particles were seen in the sonicates of uninduced cultures.

\section{Effect of temperature on proticine 3 production}

When the same induction experiment was performed with cells growing at $41^{\circ} \mathrm{C}$, no biologically active proticine 3 was detected nor proticine particles seen, although the growth rate 


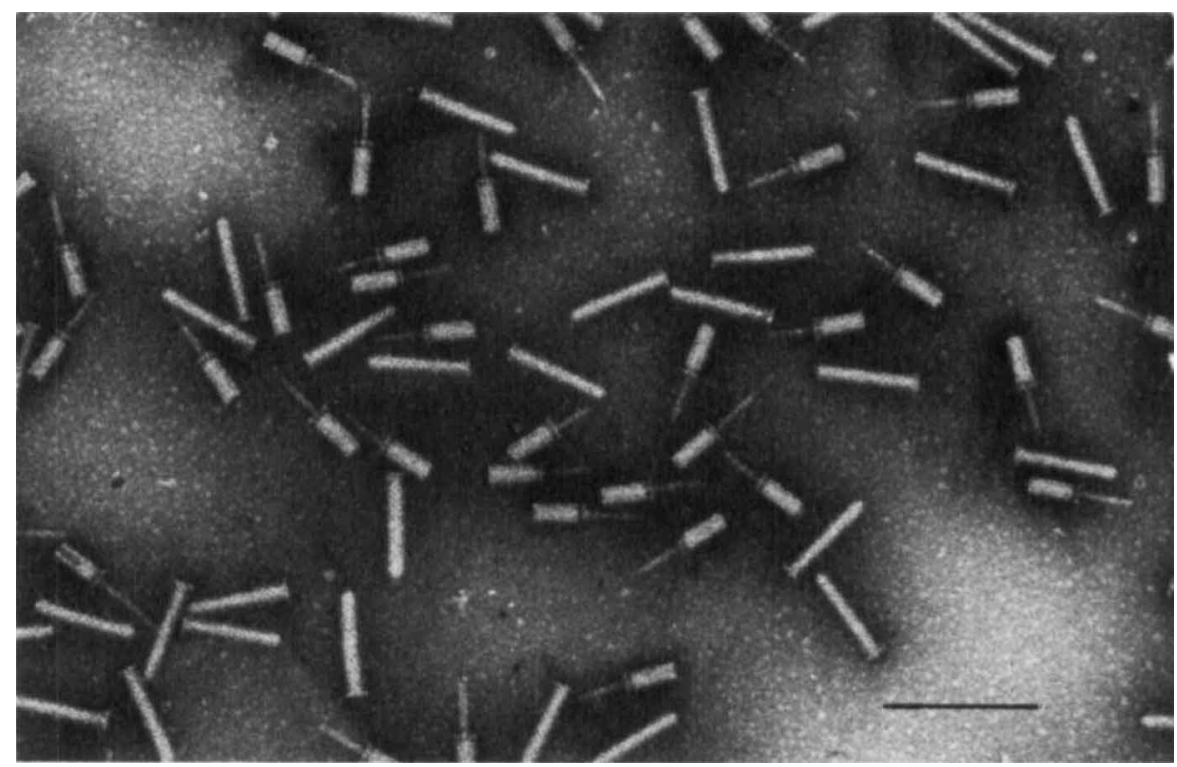

Fig. 1. Electron micrograph of purified proticine 3 showing contracted and uncontracted forms. Bar marker, $200 \mathrm{~nm}$.

of cells and the time of onset and degree of lysis were virtually indistinguishable from those given by induced cells at $30^{\circ} \mathrm{C}$.

Proticine 3 which had been produced at $30^{\circ} \mathrm{C}$ retained full biological activity after overnight incubation at $41^{\circ} \mathrm{C}$. High titres of proticine were produced when $P$. mirabilis CW977 was grown at $30^{\circ} \mathrm{C}$ in GSYE medium containing mitomycin $\mathrm{C}$ which previously had been incubated overnight at $41^{\circ} \mathrm{C}$. The failure to detect biologically active proticine and see proticine particles in induced cultures growing at $41{ }^{\circ} \mathrm{C}$ was not, therefore, due to the thermolability of either the proticine or the inducing agent but rather the result of some process in proticine synthesis being inhibited at $41^{\circ} \mathrm{C}$.

\section{Effect of temperature shifts on proticine production}

In order to try and determine when the temperature sensitive step in proticine production occurred, samples from induced cultures growing at either $30^{\circ} \mathrm{C}$ or $41^{\circ} \mathrm{C}$ were incubated at the other temperature at intervals, as shown in Fig. 4, and the supernatants from sonicated cultures tested for proticine activity. The results confirmed that biologically active proticine was not formed by induced cultures growing at $41^{\circ} \mathrm{C}$ throughout (see Fig. $4 b$ ) but was detected after $60 \mathrm{~min}$ but before $120 \mathrm{~min}$ in induced cultures growing at $30^{\circ} \mathrm{C}$ (see Fig. $4 a$ ) and that once formed, biological activity was not lost at $41^{\circ} \mathrm{C}$ (see Fig. $4 d$ ).

The synthetic processes taking place during the first $60 \mathrm{~min}$ appeared to be indifferent to temperature and if followed by a period of up to $60 \mathrm{~min}$ incubation at $30^{\circ} \mathrm{C}$ (the latter alone being insufficiently long to yield active proticine - Fig. $4 a$ ), the earlier products could be incorporated to yield biologically active proticine (see Fig. $4 c, e$ and $f$ ). Less proticine activity was detected at $180 \mathrm{~min}$ in Fig. $4(f)$ than at $180 \mathrm{~min}$ in Fig. $4(d)$ or $4(e)$. This was probably the result of the essential period of incubation at $30^{\circ} \mathrm{C}$ being postponed in Fig. $4(f)$ to a period after $120 \mathrm{~min}$ by which time there had been lysis of some cells and fewer cells were therefore available for proticine synthesis. The thermolabile stage in proticine 3 production for cells growing at $30{ }^{\circ} \mathrm{C}$ apparently occurred between $60 \mathrm{~min}$ and $120 \mathrm{~min}$ after the addition of mitoymcin $\mathrm{C}$.

Kinetics and mode of assembly of proticine 3

In an attempt to determine the kinetics of assembly of proticine 3 particles at $30^{\circ} \mathrm{C}$, samples of culture were taken from cultures at intervals during the induction process, labelled for $15 \mathrm{~min}$ 


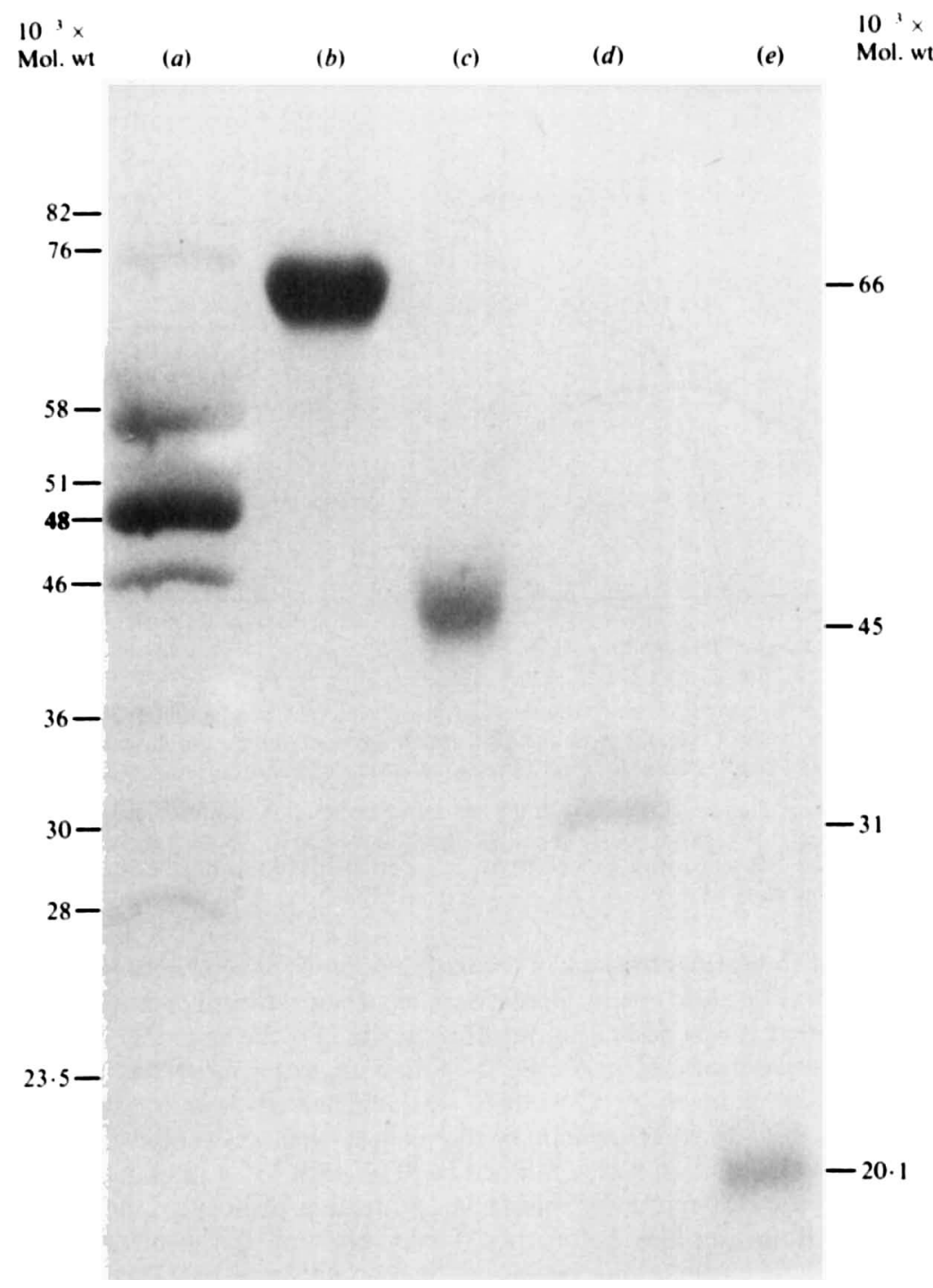

Fig. 2. SDS-PAGE of the components of purified proticine $3(a)$ and molecular weight markers bovine serum albumin $(b)$ ovalbumin $(c)$ carbonic anhydrase $(d)$ and soya bean trypsin inhibitor $(e)$.

with $\left[{ }^{3} \mathrm{H}\right]$ leucine, the cells sonicated and the sonicate centrifuged to equilibrium in $\mathrm{CsCl}$. The results (Fig. 5) show that the proteins of those cultures labelled at intervals from $90 \mathrm{~min}$ after the addition of mitomycin $C$ were incorporated mainly into particles of relative density 1.299. Analysis of all fractions showed that proticine activity coincided in position and titre exactly with the position and the amount of the labelled particles. Electron microscopy showed that the particles comprised typical proticine phage-tail-like particles of contracted (rocket-like) and noncontracted (nail-like) forms (Fig. 1). The structures in the minor peak of relative density 1.286, though fewer in number, appeared to be similar, with possibly a smaller proportion of uncontracted forms. No particles of either of these densities and no proticine activity were found in the fractions of those cultures labelled before $90 \mathrm{~min}$. Although analysis of fractions at the top of gradients showed the presence of some structural proteins, they were not assembled into sub-proticine-particles recognizable by electron microscopy. 


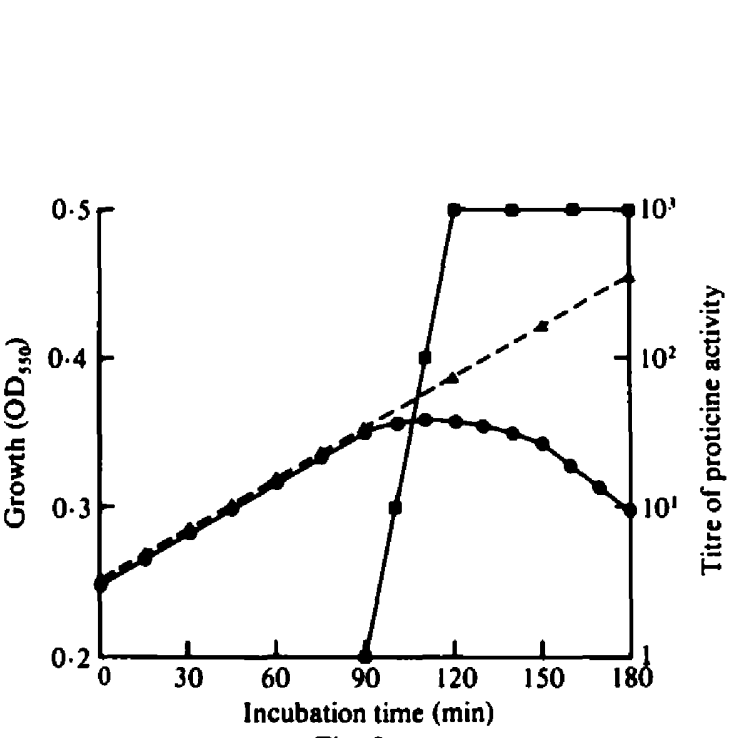

Fig. 3 (a)

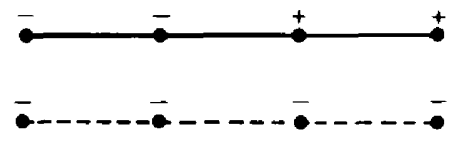

(b)

(c)

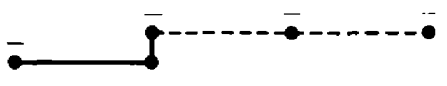

(d)

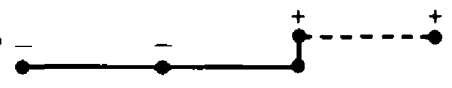

(e)
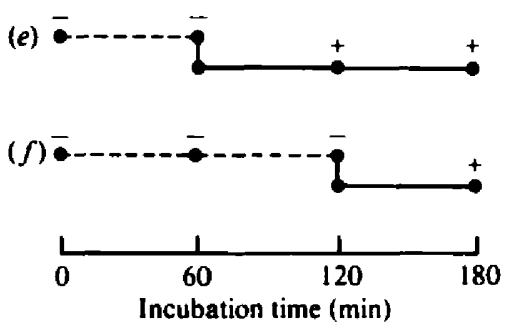

Fig. 4

Fig. 3. Effect of mitomycin C on growth and induction of proticine 3 production by P. mirabilis CW 977 in GSYE medium at $30^{\circ} \mathrm{C}$. Growth and $\square$, proticine production by mitomycin-treated cultures. Mitomycin $C$ was added at time zero. $\Delta$, Growth of untreated cultures.

Fig. 4. Effect of incubation temperature and time on the production of proticine 3 by mitomycin $\mathrm{C}$. induced cultures of P. mirabilis CW977. Incubation at $30^{\circ} \mathrm{C} ;----$, incubation at $41^{\circ} \mathrm{C}$. + , Presence and - , absence of proticine activity in supernatants of sonicated cultures. Mitomycin $\mathrm{C}$ was added at time zero.

In order to establish whether the lack of formation of proticine particles before $90 \mathrm{~min}$ in the induction process was because one or more essential structural component(s) had not yet been synthesized or whether it was because of insufficient time for the assembly of all the structural components into active proticine particles, the following experiment was performed.

A sample from an induced $30^{\circ} \mathrm{C}$ culture was labelled at $60 \mathrm{~min}$ after induction with $\left[{ }^{3} \mathrm{H}\right]$ leucine for $15 \mathrm{~min}$. Further protein synthesis was then prevented by the addition of chloramphenicol but incubation was continued at $30^{\circ} \mathrm{C}$ until $135 \mathrm{~min}$. Another culture sample was labelled for $15 \mathrm{~min} 120 \mathrm{~min}$ after induction and further protein synthesis prevented with chloramphenicol. Both samples were then sonicated and the sonicates centrifuged to equilibrium in $\mathrm{CsCl}$. The results (Fig. 6) showed that no proticine particles were formed when chloramphenicol was added at $75 \mathrm{~min}$ and incubation continued. This indicated that protein synthesis was required after $75 \mathrm{~min}$ if proticine particles were to be formed. A comparative analysis by fluorography of the proteins formed at $75 \mathrm{~min}$, where there was no formation of proticine particles, with those formed at $135 \mathrm{~min}$, when proticine particles were being formed, showed that there were two proteins formed after $75 \mathrm{~min}$ (Fig. 7). These proteins were of mol. wt 58000 and 41000 . Co-electrophoresis of the labelled proteins with unlabelled purified proticine confirmed that the protein of mol. wt 58000 was probably a structural protein of proticine 3 and that the protein of mol. wt. 41000 was not.

\section{Analysis of proticine 3 defective mutants}

Out of 120 mutants of the proticine producer strain isolated as being defective in proticine production, only 17 were reproducibly stable. Of these, none were defective solely in the production of either the protein of mol. wt 58000 or the protein of mol. wt 41000 . However, two of the mutants (D3-11 and D3-40) were defective in the production of both proteins while still able to form all the other proticine structural proteins upon induction. Both mutants were also somewhat defective in cell lysis. Analysis of induced sonicates in $\mathrm{CsCl}$ showed that neither mutant was able to assemble proticine 3 particles. 


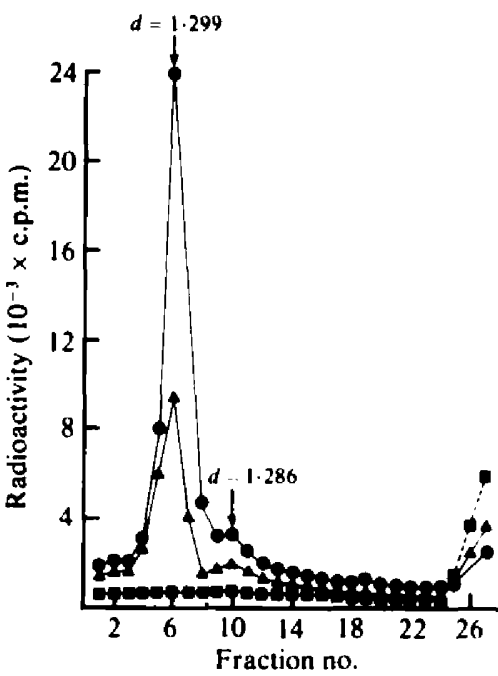

Fig. 5

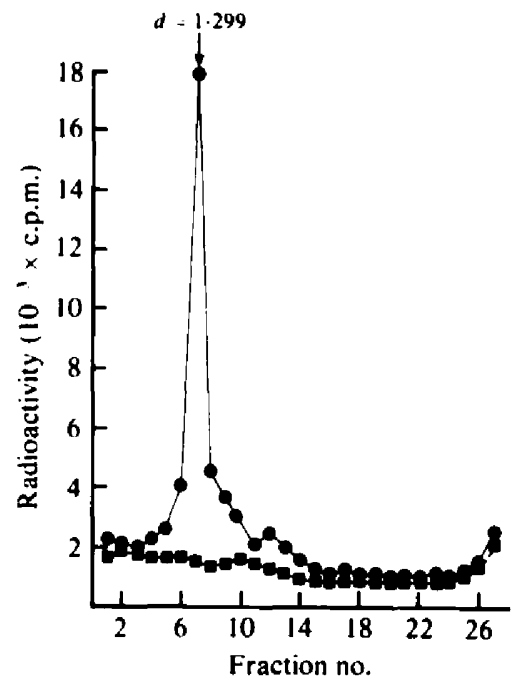

Fig. 6

Fig. 5. Isopycnic centrifugation in $\mathrm{CsCl}$ of sonicates of mitomycin $\mathrm{C}$-induced $P$. mirabilis $\mathrm{CW} 977$ cells at $30^{\circ} \mathrm{C}$ labelled for $15 \mathrm{~min}$ with $\left[{ }^{3} \mathrm{H}\right]$ leucine at $60 \mathrm{~min}(\square), 90 \mathrm{~min}(\Delta)$, and $120 \mathrm{~min}(O)$ after induction, the cells disrupted by ultrasound and the non-sedimentable fraction subjected to isopycnic centrifugation. Radioactivity in the acid-precipitable material in each gradient fraction was then determined. Biologically active proticine had a relative density of $1 \cdot 299$.

Fig. 6. Isopycnic centrifugation in $\mathrm{CsCl}$ of sonicates of $\left[{ }^{3} \mathrm{H}\right]$ leucine-labelled mitomycin $\mathrm{C}$-induced $\boldsymbol{P}$. mirabilis CW977 incubated in GSYE medium at $30^{\circ} \mathrm{C}$ for $135 \mathrm{~min}$. Cells were labelled at 60-75 min $(D)$ and $120-135 \mathrm{~min}(O)$ after induction by incubation at $30^{\circ} \mathrm{C}$ for $15 \mathrm{~min}$ in GSYE medium containing $\left[{ }^{3} \mathrm{H}\right]$ leucine and then incubating with chloramphenicol. Samples were then disrupted and treated as described in the legend to Fig. 5.

Analysis of proteins synthesized during the temperature sensitive stage in proticine production

Previous experiments showed that the temperature sensitive stage in proticine production occurred between 60 and $120 \mathrm{~min}$ after the addition of mitomycin $\mathrm{C}$ and that at $30^{\circ} \mathrm{C}$ proticine particles were being formed $90 \mathrm{~min}$ after induction but none were formed after $75 \mathrm{~min}$. In an attempt to define the events taking place during the temperature sensitive stage, an induced culture growing at $30^{\circ} \mathrm{C}$ was divided into two $70 \mathrm{~min}$ after induction: one was incubated in a prewarmed vessel at $41^{\circ} \mathrm{C}$ and the other was maintained at $30^{\circ} \mathrm{C}$. At intervals, samples from each culture were labelled for $10 \mathrm{~min}$ with $\left[{ }^{3} \mathrm{H}\right]$ leucine. An analysis of the fluorograph of the proteins formed (Fig. 8) showed that for cultures growing at $30^{\circ} \mathrm{C}$ the synthesis of the proteins of mol. wt 58000 and 41000 began simultaneously at $80 \mathrm{~min}$ and continued in increasing amounts. When the incubation temperature was raised to $41^{\circ} \mathrm{C}$, the synthesis of these proteins either did not take place or was immediately inhibited and instead there was the immediate synthesis of a new protein of mol. wt 62000 . This protein was not formed at $30^{\circ} \mathrm{C}$ and it was not a structural component of proticine.

These results showed that proticine 3 was not formed at $41{ }^{\circ} \mathrm{C}$ because at this temperature neither the proticine structural protein of mol. wt 58000 nor the protein of mol. wt 41000 of undefined function was formed.

\section{DISCUSSION}

It has been shown for the first time that production of proticine 3 requires, late in the induction process, the synthesis of a protein of mol. wt 58000 and possibly also a protein of mol. wt 41000 , and that the synthesis of both proteins and consequently proticine is inhibited at $41{ }^{\circ} \mathrm{C}$. The absolute requirement for the synthesis of the smaller protein if proticine production is to take place was not fully established, for it was impossible on a time basis to separate the events 


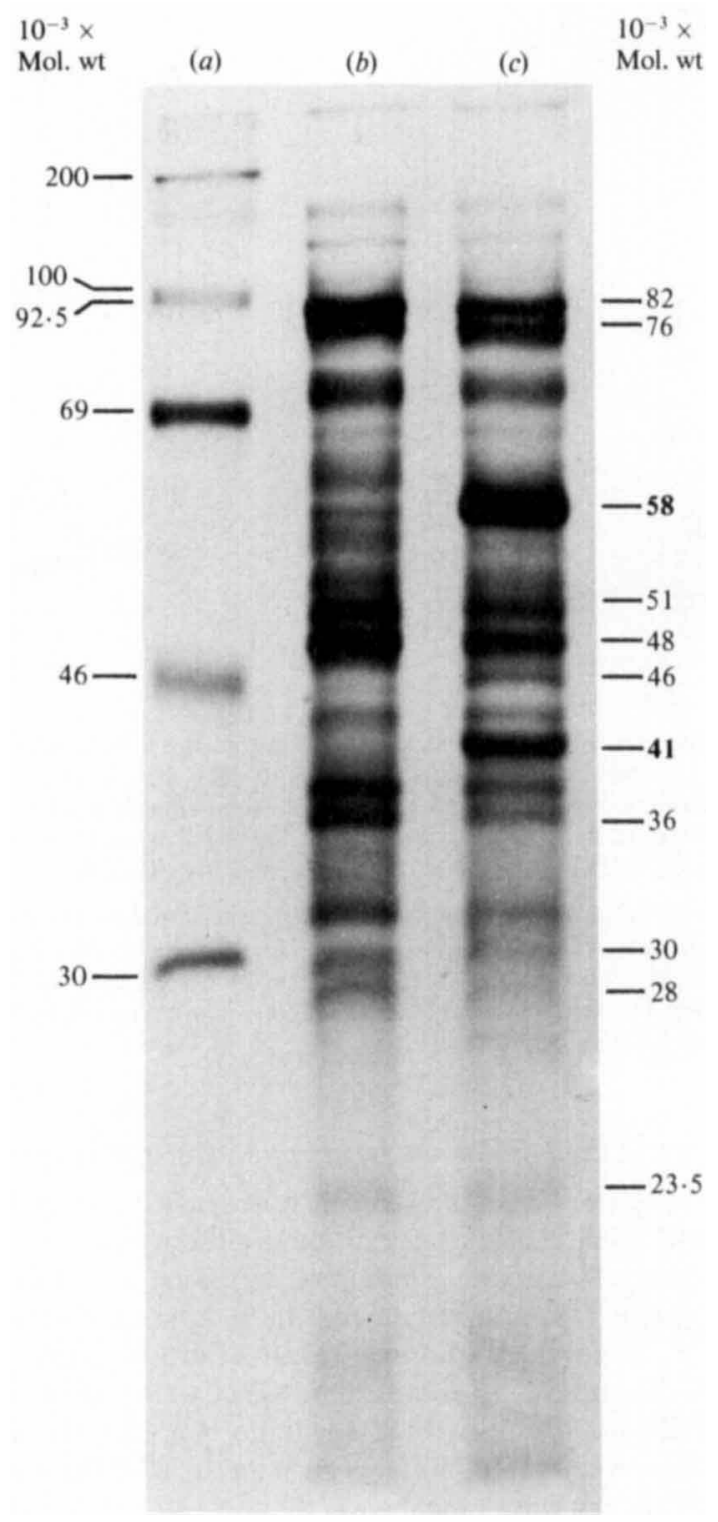

Fig 7. Fluorograph of labelled proteins of mitomycin $C$-induced cultures of $P$. mirabilis CW977 growing at $30^{\circ} \mathrm{C} .(a){ }^{1+} \mathrm{C}$-labelled protein markers; $(b, c)\left[{ }^{3} \mathrm{H}\right]$ leucine-labelled proteins at $75 \mathrm{~min}(b)$, when no proticine particles were being formed, and at $135 \mathrm{~min}(c)$, when proticine particles were being formed.

following the synthesis of the smaller protein from that of the larger protein. Furthermore, in spite of an intensive search, no mutant was found deficient solely in production of the protein of mol. wt 41000 .

Both of the mutants defective in the synthesis of the proteins of mol. wt 58000 and 41000 were somewhat defective in cell lysis. It is unlikely that either (or both) protein(s) was involved in cell lysis however, for this took place in wild-type strains at $41^{\circ} \mathrm{C}$ when neither protein was able to be synthesized. The protein of mol. wt 41000 is not a proticine structural protein and if it has a role in proticine production, being synthesized late, it is likely to be that of an assembly protein because proticine structures were not seen prior to the synthesis of this protein. 


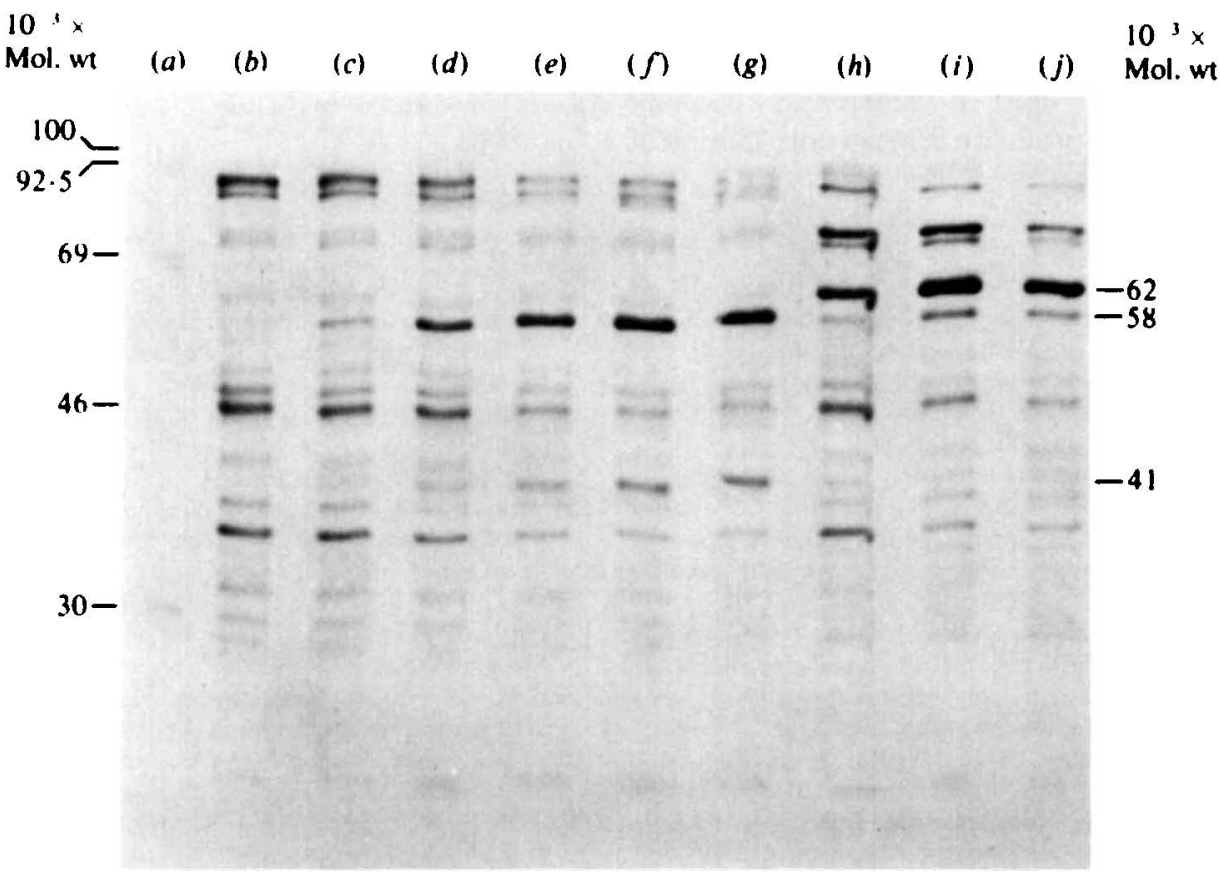

Fig. 8. Fluorograph of ${ }^{1+} \mathrm{C}$-labelled protein markers $(a)$ and the $\left[{ }^{3} \mathrm{H}\right]$ leucine proteins formed during 10 min labelling periods at $30^{\circ} \mathrm{C}$ from $60 \mathrm{~min}$ to $120 \mathrm{~min}(b-g)$ and at $41^{\circ} \mathrm{C}$ from $70 \mathrm{~min}$ to $100 \mathrm{~min}(h-$ $j)$ by mitomycin $C$-induced cultures of $P$. mirabilis $C W 977$. Mitomycin $C$ was added at time zero.

The protein of mol. wt 58000 is a structural protein of proticine and was the most intensely labelled of all the proticine proteins. Previous work (Senior, 1983), confirmed here, showed that it is the last structural proticine component to be formed and that it is not the major component of proticine particles. All the other structural components are made over long periods in the induction process, and it is thought that because the protein of mol. wt 58000 is an essential structural component made at a late stage over a short period of time just before cell lysis, it has to be made in large amounts as a compensatory measure. If proticine production is not dependent upon the synthesis of the protein of mol. wt 41000 , it is conceivable that the protein of mol. wt 58000 may play the role of the assembly protein and, once formed, cause the triggering of self-assembly of the previously formed components into a biologically active structure. It is equally true that no proticine structures were seen prior to the synthesis of this protein.

The temperature sensitive step preventing formation of the protein of mol. wt 58000 has yet to be identified. However, the similarity in both time of onset of synthesis and amount formed of this protein, and the slightly larger protein of mol. wt 62000 which was formed at $41^{\circ} \mathrm{C}$ and not at $30^{\circ} \mathrm{C}$ suggest that these proteins may be related at the translational level and that the temperature sensitive stage may be a post-translational cleavage event. This being so, cleavage would not take place at the higher temperature and the resultant protein would be too large to be assembled to produce active proticine.

Purified proticine 3 was identical both in appearance and dimension of components to that previously described (Senior, 1983) but differed a little in composition. The proteins of mol. wt 40000 and 34000 , which previously were found to be substantial components of proticine 3 were not present in the proticine 3 purified here by $\mathrm{CsCl}$ equilibrium density centrifugation. This suggests that either these two proteins were contaminants or they were proticine components removed by high salt during centrifugation which are non-essential for biological activity. The major protein band of proticine 3 of mol. wt 49000 (Senior, 1983), consisted of two proteins: a minor one of mol. wt 51000 and the major one of mol. wt 48000 . The sizes of all other component proteins of proticine were identical to those previously reported (Senior, 1983). 
Now that the structure and synthesis of proticine 3 have been determined, attention is being given to studies of its action on prokaryotic and eukaryotic cells in order to determine whether it is proticine 3 itself or the products of other associated genes which are responsible for the virulence of proticine 3 producing strains of $\boldsymbol{P}$. mirabilis.

\section{RE FER ENCES}

Adelberg, E. A., Mandel, M. \& Chen, G. C. C. (1965). Optimal conditions for mutagenesis by $N$ methyl- $N^{\prime}$-nitro- $N$-nitrosoguanidine in Escherichia coli K12. Biochemical and Biophysical Research Communications 18, 788-795.

AdLer, J. L., Burke, J. P., Martin, D. F. \& Finland, M. (1971). Proteus infection in a general hospital. I. Biochemical characteristics and antibiotic susceptibility of the organisms with special reference to proticine typing and Dienes phenomena. Annals of Internal Medicine 75, 517-530.

BONNER, W. M. \& LASKEY, R. A. (1974). A film detection method for tritium-labelled proteins and nucleic acids in polyacrylamide gels. European Journal of Biochemistry 46, 83-88.

Cradock-Watson, J. E. (1965). The production of bacteriocines by Proteus species. Zentralblatt für Bakteriologie, Parasitenkunde, Infectionskrankheiten und Hygiene (Abteilung I, Originale A) 196, 385388.

Grabow, W. O. K. \& Smit, J. A. (1967). Methionine synthesis in Proteus mirabilis. Journal of General Microbiology 46, 47-57.

LAEMMLI, U. K. (1970). Cleavage of structural proteins during the assembly of the head of bacteriophage T4. Nature, London 227, 680-685.

LAskey, R. A. \& Mills, A. D. (1975). Quantitative film detection of ${ }^{3} \mathrm{H}$ and ${ }^{14} \mathrm{C}$ in polyacrylamide gels by fluorography. European Journal of Biochemistry 56, 335-341.

SeNioR, B. W. (1977). Typing of Proteus strains by proticine production and sensitivity. Journal of Medical Microbiology 10, 7-17.

SENIOR, B. W. (1979). The special affinity of particular types of Proteus mirabilis for the urinary tract. Journal of Medical Microbiology 12, 1-8.

SENIOR, B. W. (1983). The purification, structure and synthesis of proticine 3. Journal of Medical Microbiology 16, 323-331.

Senior, B. W. \& Larsson, P. (1983). A highly discriminatory multi-typing scheme for Proteus mirabilis and Proteus inlgaris. Journal of Medical Microbiology 16, 193-202.

SENIOR, B. W. \& SWEeney, G. (1984). The association of particular types of Proteus with chronic suppurative otitis media. Journal of Medical Microbiolog. 17. 295-302.

Williams, E. W., Hawkey, P. M., Penner, J. L., Senior, B. W. \& Barton, L. J. (1983). Serious nosocomial infection caused by Morganella morganii and Proteus mirabilis in a cardiac surgery unit. Journal of Clinical Microbiology 18, 5-9. 